\title{
Extrapancreatic action of the sulphonylurea gliquidone: post-receptor effect on insulin-stimulated glycogen synthesis in rat hepatocytes in primary culture
}

\author{
F. Rinninger, D. Kirsch, H.U.Häring and W. Kemmler \\ Institut für Diabetesforschung, Munich, FRG
}

\begin{abstract}
Summary. The effects of a sulphonylurea, gliquidone, on insulin binding and the insulin induced rate of glycogen synthesis, were studied in rat hepatocytes in primary culture. Hepatocytes were cultured for $48 \mathrm{~h}$. During the second $24 \mathrm{~h}$ of this period, the hepatocytes were incubated with or without gliquidone $(5 \mathrm{mg} / \mathrm{l})$. The binding of ${ }^{125} \mathrm{I}$-insulin and the insulin stimulation of glycogen synthesis from ${ }^{14} \mathrm{C}$-glucose were measured. Gliquidone influenced neither insulin binding nor the basal rate of glycogen synthesis, but it did enhance the effect of insulin on glycogen synthesis. Responsiveness was increased by gliquidone at all insulin concentrations used $(10-10,000 \mathrm{mU} / 1)$; at $1000 \mathrm{mU} / \mathrm{l}$ the drug increased glycogen
\end{abstract}

synthesis from 310 to $430 \%$ above the basal rate. Half-maximal stimulation was reached in control cells at an insulin concentration of $95 \mathrm{mU} / 1$ and in gliquidone-treated cells at $94 \mathrm{mU} / 1$, which indicates unchanged insulin sensitivity. Based on these experiments with cultured rat hepatocytes it appears that the extrapancreatic action of gliquidone is not mediated by an effect on insulin binding.

Key words: Sulphonylurea, rat, insulin binding, insulin action, extrapancreatic effect, glycogen synthesis, rat hepatocytes in primary culture.
Sulphonylureas have been reported to increase cellular insulin binding to monocytes of diabetic patients [1], hepatic plasma membrane preparations of mice and rats $[2,3]$ and human fibroblasts in culture [4]. However, such effects were not observed using rat liver cells [5] or adipocytes [6]. In this study, we investigated the effect of the sulphonylurea drug gliquidone on insulin binding and on insulin action (i.e. glycogen synthesis) in rat hepatocytes in primary culture.

\section{Materials and methods}

\section{Cell isolation and cell culture}

Isolated hepatocytes were prepared from male Sprague-Dawley rats (body weight 170-190g, Ivanovas, Kisslegg, FRG) fed a standard diet ad libitum (Ssniff rat diet, Versuchstierdiäten, Soest, FRG) with free access to drinking water. Animals were fasted for $48 \mathrm{~h}$ before the preparation of the cells. Perfusion of the liver was performed according to the method of Berry and Friend [7], using a calcium-free Krebs Henseleit buffer ( $\mathrm{pH}$ 7.4) continuously gassed with a mixture of $\mathrm{O}_{2} / \mathrm{CO}_{2}(95: 5, \mathrm{v} / \mathrm{v})$ and containing collagenase $0.6 \mathrm{~g} / 1$ (CLS I, $166 \mathrm{U} /$ $\mathrm{mg}$, Worthington Biochemicals, Freehold, New Jersey, USA).

After 20 min of perfusion, hepatocytes and non-parenchymal cells were separated by filtration through a nylon mesh $(28 \mu \mathrm{m})$. To remove collagenase, the cell suspension was washed three times with perfusion medium, centrifuged ( $60 \mathrm{~s}$ at $50 \mathrm{~g}$ ) and the supernatant discarded.
After the third centrifugation the cells were taken up in culture medium and counted by using a manual haemocytometer under the microscope (Diavert, Leitz, Wetzlar, FRG). Viability of the hepatocytes used for the experiments was $>95 \%$ as judged by Trypan blue exclusion. Hepatocytes $\left(2.5 \times 10^{6}\right)$ were inoculated (in $3.5 \mathrm{ml}$ of culture medium) in each $60 \times 15$-mm plastic culture dish (Greiner, Nuertingen, FRG) [8]. The monolayers were cultured for $48 \mathrm{~h}$ at a temperature of $37^{\circ} \mathrm{C}$ in an atmosphere of air saturated with water vapour. Modified Dulbecco's minimal essential culture medium was used [Seromed, Munich, FRG; HEPES ( $20 \mathrm{mmol} / \mathrm{l}), \mathrm{NaHCO}_{3}(4 \mathrm{mmol} / \mathrm{l})$, glutamine $(4 \mathrm{mmol} / 1)$, lactate $(5 \mathrm{mmol} / 1)$, pyruvate $(0.5 \mathrm{mmol} / 1)$, glucose $(10 \mathrm{mmol} / \mathrm{l})$, penicillin $(100 \mathrm{U} / \mathrm{ml})$ and streptomycin $(100 \mathrm{mg} / \mathrm{l})]$.

For the first $4 \mathrm{~h}$ of culture, this medium was supplemented with $10 \%$ fetal calf serum (Seromed) to improve monolayer formation. After $4 \mathrm{~h}$ in culture, the medium was changed and fresh culture medium without fetal calf serum was added, but supplemented with bovine serum albumin $(1.0 \mathrm{~g} / 1)$ and insulin $(150 \mathrm{mU} / \mathrm{l})$. During the second day of culture, the culture medium as described above contained no insulin, but did include serum albumin $(1.0 \mathrm{~g} / 1$, all dishes) with or without gliquidone $(5.0 \mathrm{mg} / \mathrm{l})$ (gift from Dr. E. Rupprecht, Thomae, Biberach, FRG). This culture medium was changed every $6 \mathrm{~h}$. All assays were performed after $48 \mathrm{~h}$ of culture.

\section{Insulin binding}

Fresh culture medium, as during the second day of culture but without antibiotics, was added to the monolayers before the binding experiment. The temperature was lowered to $20^{\circ} \mathrm{C}$ and after $1 \mathrm{~h}$ the medium was exchanged against identical culture medium $(2 \mathrm{ml})$ 
Table 1. Binding of ${ }^{125} \mathrm{I}$-insulin to rat hepatocytes in primary culture incubated with or without gliquidone $(5.0 \mathrm{mg} / \mathrm{l})$

\begin{tabular}{rcc}
\hline $\begin{array}{l}\text { Insulin } \\
\text { concentration } \\
(\mathrm{mU} / 1)\end{array}$ & \multicolumn{2}{c}{ Insulin binding (mU/g protein) } \\
\cline { 2 - 3 } & Control cells & $\begin{array}{l}\text { Gliquidone- } \\
\text { treated cells }\end{array}$ \\
\hline 1.5 & $0.22 \pm 0.008$ & $0.24 \pm 0.01$ \\
26.5 & $2.6 \pm 0.26$ & $2.8 \pm 0.24$ \\
51.5 & $3.9 \pm 0.49$ & $4.1 \pm 0.54$ \\
126.5 & $7.2 \pm 0.82$ & $7.1 \pm 0.84$ \\
251.5 & $10.4 \pm 1.5$ & $9.8 \pm 1.6$ \\
501.5 & $13.2 \pm 1.7$ & $13.1 \pm 1.7$ \\
5001.5 & $30.4 \pm 2.4$ & $31.4 \pm 4.4$ \\
\hline
\end{tabular}

Results represent mean $\pm \mathrm{SEM}$ of four separate experiments performed in duplicate

Table 2. Effect of gliquidone on DNA, protein and glycogen content of rat hepatocytes in primary culture

\begin{tabular}{llll}
\hline & $\begin{array}{l}\text { DNA } \\
(\mu \mathrm{g} / \text { dish })\end{array}$ & $\begin{array}{l}\text { Protein } \\
(\mu \mathrm{g} / \text { dish })\end{array}$ & $\begin{array}{l}\text { Glycogen } \\
\text { (mmol glucose } \\
\text { g protein })\end{array}$ \\
\hline $\begin{array}{c}\text { Control } \\
\text { hepatocytes }\end{array}$ & $11.9 \pm 1.5(6)$ & $2103 \pm 201(6)$ & $148.3 \pm 37.2(5)$ \\
$\begin{array}{c}\text { Gliquidone- } \\
\text { treated } \\
\text { hepatocytes }\end{array}$ & $11.7 \pm 1.8(6)$ & $2049 \pm 192(6)$ & $147.1 \pm 21.0(5)$ \\
\hline
\end{tabular}

Results represent mean $\pm S E M$ with the number of experiments given in parentheses. Experiments were performed in duplicate.

${ }^{a}$ Gliquidone concentration $5.0 \mathrm{mg} / 1$

which contained in addition labelled insulin, (1.5 mU/1 (Mono- ${ }^{125} \mathrm{I}$ (TYR A 14)-insulin, $183 \mu \mathrm{Ci} / \mu \mathrm{g}$, Novo, Copenhagen, Denmark) alone or with unlabelled insulin (porcine monocomponent insulin $25-5000 \mathrm{mU} / \mathrm{l}$, Novo). Equilibrium binding was reached after $2 \mathrm{~h}$ of incubation at $20^{\circ} \mathrm{C}$ (data not shown). The supernatant was then aspirated to remove unbound insulin and the monolayer was washed four times with buffered saline ( $4 \mathrm{ml}$, Tris (Tris(hydroxymethyl)-aminomethan, Merck, Darmstadt, FRG) $(5 \mathrm{mmol} / 1), \mathrm{NaCl}(0.154 \mathrm{~mol} / 1)$, pH $\left.7.4,4^{\circ} \mathrm{C}\right)$. The cells were taken off in $2 \times 1 \mathrm{ml} \mathrm{NaOH}(0.2 \mathrm{~mol} / 1$, $4^{\circ} \mathrm{C}$ ) and counted for radioactivity (NE 1600, Nuclear Enterprises, Edinburgh, UK). The binding data were corrected for protein content, insulin degradation and non-specific binding, i.e. the binding of labelled insulin in the presence of insulin $1000 \mathrm{U} / 1$.

\section{Glycogen synthesis rate}

The assay for insulin-stimulated incorporation of labelled glucose (D- $\left(\mathrm{U}_{-}{ }^{14} \mathrm{C}\right)$ glucose, $270 \mathrm{mCi} / \mathrm{mmol}$, Amersham International, Braunschweig, FRG) into glycogen was a modification of the method of Bernaert et al. [9]. Fresh culture medium, as during the second day of culture but without antibiotics, was added $1 \mathrm{~h}$ before the glycogen synthesis measurements. Then hepatocyte monolayers were incubated for $2 \mathrm{~h}$ at $37^{\circ} \mathrm{C}$ in $2 \mathrm{ml}$ of identical culture medium with glucose (final concentration $10 \mathrm{mmol} / 1$, including $\mathrm{D}-\left(\mathrm{U}^{-14} \mathrm{C}\right)$ glucose $\left.0.1 \mathrm{mCi} / 1\right)$, with or without insulin $(0-10,000 \mathrm{mU} / 1)$, with or without gliquidone $(5.0 \mathrm{mg} / \mathrm{l})$. Blank control dishes were incubated at $4^{\circ} \mathrm{C}$ with the same medium as above, including labelled glucose. The incubation was stopped by four washes with buffered saline (see above, $4 \mathrm{ml}, 4^{\circ} \mathrm{C}$ ) to remove labelled glucose. Afterwards $\mathrm{KOH}\left(300 \mathrm{~g} / 1,1 \mathrm{ml}, 4^{\circ} \mathrm{C}\right)$ was added for $30 \mathrm{~min}$. The solubilized material plus a further $1 \mathrm{ml} \mathrm{KOH}$ were transferred to tubes containing carrier glycogen $(2 \mathrm{mg})$ and the mixture was boiled for $30 \mathrm{~min}$. Following cooling on ice, glycogen was precipitated by the addition of ethanol $\left(4^{\circ} \mathrm{C}\right.$, final concentration
$66 \%$ by volume) and after centrifugation $(10 \mathrm{~min}, 1000 \mathrm{~g})$ the residue was washed again with ethanol and finally resuspended in water. Radioactivity was counted in scintillation fluid (Kontrogel, Kontron, Zürich, Switzerland) in a liquid scintillation counter (Packard, Downers Grove, Illinois, USA). Samples were corrected for blank control values and for protein content. Gliquidone had no influence on the glycogen extraction procedure as tested before the experiments were performed.

\section{Glycogen content}

Medium was removed after $48 \mathrm{~h}$ of culture and the hepatocyte monolayers were washed four times with buffered saline (see above, $4 \mathrm{ml}$, $\left.4^{\circ} \mathrm{C}\right)$. Then $2 \times 1 \mathrm{ml}$ trichloroacetic acid $\left(75 \mathrm{~g} / 1,4^{\circ} \mathrm{C}\right)$ were added. The monolayers were scraped off and the suspension was transferred to tubes which were centrifuged $(10 \mathrm{~min}, 8000 \mathrm{~g})$. From the resulting supernatant the acid was extracted by four treatments with water-saturated ether $(4 \times$ volume). After neutralization and freezing in liquid air, the samples were lyophilized, redissolved in sodium-acetate-buffer $(200 \mathrm{mmol} / 1, \mathrm{pH} 4.8)$ and the glycogen content determined photometrically after digestion with amyloglucosidase (Boehringer, Mannheim, FRG) as described by Keppler et al. [10].

\section{Protein and DNA-determination}

After $48 \mathrm{~h}$ of culture the monolayers were washed four times with buffered saline (see above, $4 \mathrm{ml}, 4^{\circ} \mathrm{C}$ ). For protein determination, the cells were solubilized in $2 \times 1 \mathrm{ml}$ trichloroacetic acid $(50 \mathrm{~g} / 1)$. Protein determination was performed according to the method of Lowry et al. [11], using bovine serum albumin fraction V (Sigma, Taufkirchen, FRG) as standard. For DNA-determination, the cells were solubilized in $2 \times 1 \mathrm{ml}$ perchloric acid $(100 \mathrm{~g} / 1)$. DNA was measured according to Richards [12].

\section{Statistical analysis}

Statistical analysis was performed by the two-tailed paired Student's $\mathrm{t}$-test. Results are given as mean \pm SEM.

\section{Results}

No difference in ${ }^{125} \mathrm{I}$-insulin binding to rat hepatocytes in primary culture was observed when gliquidone-treated cells were compared with control cells (Table 1 ). The concentration of gliquidone used is $2 \cdot 5$-fold higher than the level measured in peripheral venous plasma in vivo [13]. After absorption from the gut this concentration might be reached in the liver, the main organ of degradation of the drug [14]. DNA and protein content of monolayers incubated in the presence and absence of gliquidone were identical, which indicates that any proliferation or breakdown of the cells were equal in both groups (Table 2). As further controls insulin degradation and insulin dissociation were investigated. After ${ }^{125} \mathrm{I}$-insulin binding $\left(2 \mathrm{~h}\right.$ at $\left.20^{\circ} \mathrm{C}\right)$, approximately $7 \%$ of the total insulin was degraded in both groups, as measured by trichloroacetic acid $(100 \mathrm{~g} / \mathrm{l})$ precipitation. Dissociation of ${ }^{125} \mathrm{I}$-insulin, measured after binding $(2 \mathrm{~h}$ at $20^{\circ} \mathrm{C}$ ), was also unaffected by gliquidone (data not shown).

As a measure of insulin action, the insulin-stimulated glycogen synthesis rate from labelled glucose was in- 


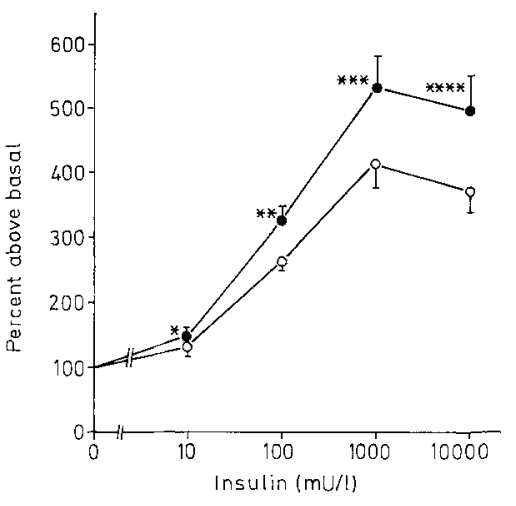

Fig. 1. Effect of gliquidone on the insulin-stimulated glycogen synthesis rate in rat hepatocytes. $\mathrm{O}-\mathrm{O}$ : control cells, - : cells treated with gliquidone $(5.0 \mathrm{mg} / \mathrm{l})$. Basal rate of glucose incorporation into glycogen was $17.5 \pm 4.5 \mathrm{mmol}$ glucose $\cdot g$ protein ${ }^{-1} \cdot 1 \mathrm{~h}^{-1}$ in control cells and $18.1 \pm 4.4 \mathrm{mmol}$ glucose $\cdot g$ protein ${ }^{-1} \cdot \mathbf{h}^{-1}$ in gliquidonetreated cells. Results are expressed as mean \pm SEM from six separate experiments performed in duplicate.

${ }^{*} p<0.05, * * p<0.005, * * * p<0.0005, * * * * p<0.0125$

vestigated. Insulin $(10-10,000 \mathrm{mU} / 1)$ stimulated glycogen synthesis in a dose-dependent manner; the maximum of approximately $310 \%$ above basal was reached at an insulin concentration of $1000 \mathrm{mU} / 1$ (Fig. 1). Gliquidone did not change the basal rate of glycogen synthesis, whereas it did significantly increase the insulinstimulated rate at all insulin concentrations (from 310\% to $430 \%$ in presence of insulin $1000 \mathrm{mU} / 1$ ). Half-maximal stimulation was reached in both groups at the same insulin concentration (control, $94 \pm 5 \mathrm{mU} / 1$; and gliquidone-treated cells, $94 \pm 11 \mathrm{mU} / 1$; mean \pm SEM), which indicates that gliquidone changed insulin responsiveness but not insulin sensitivity. In accordance with the rate of glycogen synthesis, gliquidone did not change the basal glycogen content of hepatocytes after culture (Table 2).

\section{Discussion}

This study shows that the sulphonylurea gliquidone increases the insulin responsiveness of glycogen synthesis in primary cultures of rat hepatocytes without affecting insulin binding and insulin sensitivity. This is in agreement with other findings in vitro. Salhanick et al. [15] also observed an increased insulin responsiveness under the influence of tolazamide in primary cultures of hepatocytes, studying insulin-stimulated lipogenesis. Neither the sensitivity of the insulin effect on lipogenesis nor binding were influenced by the drug. Another important target tissue of insulin, adipose tissue in culture, showed a potentiation of insulin-stimulated glucose uptake under the influence of a sulphonylurea [6]. Again no change in insulin sensitivity or insulin binding was observed. Thus, in several systems where insulin action has been tested in vitro, a post-receptor effect of these drugs could be demonstrated.
On the other hand, we and the two other groups [6, 15] could not find an effect of sulphonylurea on insulin binding, dissociation or degradation. This is in agreement with a number of other studies in vitro. In hepatocytes in culture, Fleig et al. [5] could not observe a change in insulin binding in glibenclamide-treated cells. In other culture systems with adipocytes $[6,16]$, human skin fibroblasts, IM-9 lymphoblasts, MCF-7 human mammary carcinoma or $\mathrm{H} 35$ rat hepatoma cells [17] different sulphonylurea drugs also showed no effect on insulin binding. Only Prince and Olefsky [4] observed a modest increase in insulin receptors in human fibroblasts in culture. Thus, the insulin receptor of tissues studied in vitro was not influenced by sulphonylureas except in one study with human fibroblasts [4]. This is in contrast to a number of studies in vivo.

Bachmann et al. [2] and Feinglos and Lebovitz [3] observed enhanced insulin binding to purified liver plasma-membrane preparations from rats and mice, treated orally with gliquidone or glipizide. Also an increased number of insulin receptors was observed in circulating monocytes of non-insulin-dependent diabetic patients treated with sulphonylureas $[1,18]$. It is at present not clear why these findings in vivo are not in agreement with the majority of studies in vitro. Several explanations seem possible: (1) In the experiments where an increase in binding was observed, the drug was given to animals or patients over a long period. Thus the effect of the sulphonylureas on binding might be very slow and has to be studied in culture systems for longer periods. (2) The effect observed in vivo might be secondary to changes in the insulin serum levels during the sulphonylurea therapy. It is well established that the insulin receptor capacity is inversely related to the insulin plasma levels in the state of insulin deficiency [22, 23]. Decreasing insulin levels during sulphonylurea therapy were observed earlier by different investigators $[19,20]$ and also recently by Lunetta et al. [21] and by Beck-Nielsen et al. [18] with adult-onset diabetic patients. (3) Another explanation for the discrepancy could be that factors as yet unknown might be involved, since in all experiments where an increase in insulin binding could be observed the drug was given orally.

In summary, it may be postulated that sulphonylurea drugs have extrapancreatic effects which might be independent of interactions between insulin and its receptor on the surface of peripheral cells.

Acknowledgements. We thank M. Kroiß for her expert technical assistance.

\section{References}

1. Olefsky JM, Reaven GM (1976) Effects of sulfonylurea therapy on insulin binding to mononuclear leukocytes of diabetic patients. Am J Med 60: 89-95

2. Bachmann W, Böttger I, Haslbeck M, Mehnert H (1979) Extrapancreatic action of sulfonylureas: effect of gliquidone on insulin 
and glucagon binding to rat liver plasma membranes. Eur $\mathbf{J}$ Clin Invest 9: 411-415

3. Feinglos MN, Lebovitz HE (1978) Sulfonylureas increase the number of insulin receptors. Nature 276:184-185

4. Prince MJ, Olefsky JM (1980) Direct in vitro effect of a sulfonylurea to increase human fibroblast insulin receptors. J Clin Invest 66: 608-611

5. Fleig WE, Noether-Fleig G, Fussgaenger R, Ditschuneit H (1982) Insulin binding in primary cultures of adult hepatocytes: effects of insulin and sulfonylurea. Eur J Clin Invest 67: 12 (Abstract)

6. Maloff BL, Lockwood DH (1981) In vitro effects of a sulfonylurea on insulin action in adipocytes. J Clin Invest 68: 85-90

7. Berry MN, Friend DS (1969) High-yield preparation of isolated rat liver parenchymal cells. J Cell Biol 43: 506-520

8. Wanson JC, Drochmans P, Mosselmans R, Ronveaux MF (1977) Adult rat hepatocytes in primary monolayer culture. $\mathrm{J}$ Cell Biol 74: $858-877$

9. Bernaert D, Wanson JC, Drochmans P, Popowski A (1977) Effect on insulin on ultrastructure and glycogenesis in primary cultures of adult rat hepatocytes. J Cell Biol 74: 878-900

10. Keppler D, Decker K (1970) Glycogenbestimmung mit Amyloglucosidase. In: Bergmeyer HU (ed) Methoden der enzymatischen Analyse, 2. Auflage. Verlag Chemie Weinheim, Bergstraße, pp 1089-1094

11. Lowry OH, Rosebrough NJ, Farr AL, Randall RL (1951) Protein measurement with the fohn phenol reagent. J Biol Chem 193: 265-275

12. Richards GM (1974) Modifications of the diphenylamine reaction giving increased sensitivity and simplicity in the estimation of DNA. Anal Biochem 57: 369-376

13. Zilker Th, Hales CN, Siddle K, Bottermann P(1975) Serumspiegel von Glurenorm in Abhängigkeit von Dosishöhe und Dosierungsintervall. Therapiewoche 25:35-47

14. Jackson JE, Bressler R (1981) Clinical pharmacology of sulphonylurea hypoglycaemic agents: Part 1 . Drugs $22: 211-245$

15. Salhanick AI, Konowitz P, Amatruda JM (1983) Potentiation of insulin action by a sulfonylurea in primary cultures of hepatocytes from normal and diabetic rats. Diabetes 32: 206-212
16. Joost HG, Arend W, Holze SA (1982) Effects of tolbutamide on insulin binding to isolated cells of the rat. Biochem Pharmacol 31: $1227-1231$

17. Vigneri R, Pezzino V, Wong KY, Goldfine ID (1982) Comparison of the in vitro effect of biguanides and sulfonylureas on insulin binding to its receptors in target cells. J Clin Endocrinol Metab 54: $95-100$

18. Beck-Nielsen H, Pedersen O, Lindskow HO (1979) Increased insulin sensitivity and cellular insulin binding in obese diabetics following treatment with glibenclamide. Acta Endocrinol 90: 451-462

19. Duckworth WC, Solomon SS, Kitabchi AE (1972) Effect of chronic sulfonylurea therapy on plasma insulin and proinsulin levels. $\mathbf{J}$ Clin Endocrinol Metab 35: 585-591

20. Reaven G, Dray J (1967) Effect of chlorpropamide on serum glucose and immunoreactive insulin concentrations in patients with maturity-onset diabetes mellitus. Diabetes 16: 487-492

21. Lunetta M, Leonardi S, Rapisarda S, Mughini L (1981) Effects of short and longterm glibenclamide treatment on the response of pancreatic alpha and beta cells to oral glucose loading in adultonset diabetes. Curr Ther Res Clin Exp 30: 50-59

22. Kemmler W, Häring HU (1982) Insulin binding and action in antibody-induced diabetes in the rat. Diabetologia 23:517-520

23. Hepp KD, Langley J, Funcke HJ, Renner R, Kemmler W (1975) Increased insulin binding capacity of liver membranes from diabetic Chinese hamsters. Nature 258: 154

Received: 29 August 1983

and in revised form: 8 February 1984

Dr. med. Franz Rinninger

Institut für Diabetesforschung

Kölner Platz 1

D-8000 München 40

FRG 